\section{Effect of reduced water potential on seed germination of a forest tree: a hydrotime approach}

\author{
Luís Felipe Daibes*1 ${ }^{1 D}$, Victor J.M. Cardoso ${ }^{1}$ iD
}

ABSTRACT: Hydrotime $\left(\theta_{H}\right)$ models provide information on seed tolerance to low water potential and time to germination under different conditions. Here it was evaluated the capacity of graphic and probit model to describe germination parameters and germination times $(\mathrm{t}$ ) in a tropical legume (Peltophorum dubium). Germination tests were conducted under reduced water potentials (polyethylene glycol solutions from 0 to $-1.2 \mathrm{MPa}$ ) at 25 ${ }^{\circ} \mathrm{C}$. Regression lines were applied to investigate the relationship between germination rates $(1 / \mathrm{t})$ and water potential for different germination percentages (fractions 10, 30, 50 and $70 \%)$. Those regressions were used in the graphic model to calculate $\theta_{H}(1 /$ slope) and determine the base water potential $(\Psi \mathrm{b})$ as the point which the line intercepts the $x$-axis $(\mathrm{G} \%=0)$. In the probit model, germination percentages were transformed to probit units and plotted against $\Psi \mathrm{b}$-values to describe germination response under a single regression line. Values for $\theta_{H}$ varied from 1.8 to $2.0 \mathrm{MPa}$ day in both models, and $\Psi \mathrm{b}$ showed a normal distribution, as presupposed by the probit model. Predicted germination times (t10 and t50) mostly fell within observed times, thus showing biological relevance of the models to describe the effects of water potential on seed germination.

Index terms: osmotic potential, Peltophorum, probit, psi-base, hydrotime model.

\section{Efeito da redução do potencial hídrico na germinação de sementes de uma árvore tropical: uma abordagem do tempo hídrico}

RESUMO: Modelos do tempo hídrico $\left(\theta_{H}\right)$ explicam a tolerância das sementes a potenciais hídricos reduzidos. Neste estudo, foi avaliada a capacidade dos modelos gráfico e probit para descrever parâmetros germinativos e tempos de germinação em uma leguminosa tropical (Peltophorum dubium). Foram conduzidos testes de germinação sob potenciais hídricos reduzidos ( 0 a $-1.2 \mathrm{MPa}$ ) a $25^{\circ} \mathrm{C}$ e utilizadas regressões para investigar a relação entre a taxa de germinação (1/t) e potencial hídrico para diferentes frações (10, 30, 50 e $70 \%$ de germinação). As regressões foram utilizadas no modelo gráfico para calcular $\theta_{H}(1 /$ inclinação da reta entre taxa de germinação e potencial hídrico) e determinar os valores de potencial hídrico base $(\Psi \mathrm{b})$, ponto no qual a reta intercepta o eixo $\times(G \%=0)$. No modelo de probit, as porcentagens de germinação foram transformadas em probit e plotadas contra os valores de $\Psi \mathrm{b}$ para descrever a germinação em uma única reta. Os valores de $\theta_{H}$ variaram de 1.8 a $2.0 \mathrm{MPa}$ dia em ambos os modelos, e $\Psi \mathrm{b}$ apresentou distribuição normal, conforme pressuposto pelo modelo probit. A maioria dos tempos de germinação (t10 e t50) preditos ficou dentro dos tempos observados, demonstrando relevância biológica dos modelos na descrição dos efeitos do potencial hídrico na germinação.

Termos para indexação: potencial osmótico, Peltophorum, probit, psi-base, modelo de tempo hídrico.
Journal of Seed Science, v.42 e202042003, 2020

http://dx.doi.org/10.1590/2317$1545 v 42224519$ 


\section{INTRODUCTION}

Water uptake is the principal factor starting the germination process, promoting cell respiration, DNA synthesis and growth (Bewley et al., 2013). Therefore, water potential $(\Psi)$ strongly drives seed germination, by regulating the amount of water able to realize work in a solution. In a physiological sense, the decrease of water potential reduces germination capacity (G\%), as well as the rate of the germination process (Gummerson, 1986; Bradford, 1995). Therefore, the germination rate $(G R$, inverse of germination time, $t)$ seems to linearly decrease with negative $\Psi$-values, until the point at which seeds stop the germination process due to low water potential (base water potential, or $\Psi \mathrm{b}$ ).

Because seeds can only accomplish germination above a $\Psi$ b-value, threshold models can be developed to describe seed germination responses to water potential (Bradford, 1990; Alvarado and Bradford, 2002; Finch-Savage, 2004). Above $\Psi \mathrm{b}$, seeds require an accumulated $\Psi$ (MPa) through time (hydrotime, or $\theta_{H}$ ) to germinate and, therefore, hydrotime models were used to describe germination responses to reduced water potentials, mostly in crops (e.g. Gummerson, 1986; Dahal and Bradford, 1994; Windauer et al., 2007). Concerning native species, few studies in current literature investigated such threshold models regarding water relations and seed germination of tropical trees (Daws et al., 2008). Some studies evaluated the role of $\Psi$ on seed germination of Brazilian species (Botelho and Perez, 2001; Fonseca and Perez, 2003; Rego et al., 2007), but rarely explaining whether germination would fit the presupposes of hydrotime models (Cardoso and Pereira, 2008; Oliveira et al., 2019). Most attention regards to the role of temperature, rather than water potential, as described by thermal time models in neotropical species (Cardoso and Pereira, 2009; Pires et al., 2009; Daibes and Cardoso, 2018; Duarte et al., 2018).

Furthermore, seed germination can be expressed in different germination fractions (percentages), given the distribution and variation of time to germinate within seeds in a population (Garcia-Huidobro et al., 1982; Gummerson, 1986; Alvarado and Bradford, 2002). Hence, GR (germination rate) decreases with $\Psi$, but also varies according with the percentiles of seeds (i.e. seeds within the $10 \%$ percentile do germinate faster than the seeds within the 50 or $70 \%$ percentile). Likewise, $\theta_{H}$ requirements are related to $G R$ and different $\Psi \mathrm{b}$-values might be expected for different fractions of seed germination (Bradford, 1990; Alvarado and Bradford, 2002). This might be important to understand the proportion of seeds which can be recruited in seasonal environments, where seeds are subjected to desiccation during the dry season, facing low water potentials in the soil seedbanks (Cavallaro et al., 2016).

Therefore, this study aimed to investigate the role of water potential in seed germination of Peltophorum dubium, a tropical tree legume typically occurring in South American seasonal forests. Specifically, it was addressed how hydrotime models (graphic model and probit model) would describe seed germination of the species, explaining hydrotime requirements and $\Psi$ b. Using non-dormant seeds (previously alleviated from physical dormancy), it was hypothesized that seed germination would behave such as predicted by the model, following presupposes of graphical model (linear relationship of germination rate with decreasing of $\Psi$-values) and repeated probit model (normal distribution of $\Psi \mathrm{b}$ with a single value of hydrotime requirement).

\section{MATERIAL AND METHODS}

\section{Seed harvesting}

Seeds were obtained from a certified producer located in the municipality of Porto Ferreira $\left(21^{\circ} 3^{\prime} \mathrm{S} ; 47^{\circ} 2^{\prime} \mathrm{W}\right.$; state of São Paulo, Brazil). The harvesting site shows average temperatures from 19 to $25^{\circ} \mathrm{C}$ and mean annual precipitation of $1500 \mathrm{~mm}$ (Daibes and Cardoso, 2018). The species has a widespread distribution throughout South America, mostly occurring in seasonal forests from the Paraguai-Paraná Basin to the state of Bahia (Barneby, 1996). The harvesting was performed in May 2011, in different mother plants and seeds kept stored within the pods (indehiscent fruit) inside paper bags under low temperatures $\left(\sim 5^{\circ} \mathrm{C}\right)$ until their use in the experiments, few months later. Dispersal period may range from April to December, and ripened fruits remain attached to the trees for several months (Carvalho, 2002). The total 
viability of seeds was high by the beginning of germination trials ( $90 \%)$ and no light requirement was detected in $P$. dubium seeds (Perez et al., 2001).

\section{Germination trials}

To conduct germination tests under different water potentials, seeds were removed from the pods and carefully screened to remove malformed and/or predated seeds. Then, seeds were individually scarified with a sandpaper to overcome physical dormancy. Once scarified, seeds were expected to behave as non-dormant seeds in the germination trials (Daibes and Cardoso, 2018). Different water potentials were obtained by aqueous solutions of PEG 6000 (polyethylene glycol), ranging from zero (distilled water) to $-1.5 \mathrm{MPa}(0 ;-0.3 ;-0.5 ;-0.7 ;-0.9 ;-1.1 ;-1.3 ;-1.5)$. PEG solutions were prepared according to Villela et al. (1991), as adapted from Michel and Kaufmann (1973). Seeds were then set to germinate on a double layer of filter paper soaked in at least $6 \mathrm{~mL}$ of the corresponding PEG solution in Petri dishes (90 mm), sealed with plastic film to prevent evaporation of the solution.

Three replicates of twenty seeds were used in each water potential treatment, and germination tests were conducted in germination chambers under the constant temperature of $25^{\circ} \mathrm{C}$, considered within the range of optimal conditions for seed germination of the species (Daibes and Cardoso, 2018). Because $P$. dubium seeds are non-photoblastic, all germination trials were conducted in the dark. Seed germination (radicle protrusion) was daily counted for one month or until the germination of all seeds in the plate. At each counting, Petri dishes were carefully re-wrapped again in the plastic film. By the end of the trials, remaining seeds were visually inspected to attest viability and scored as dead.

\section{Data analysis and hydrotime modeling}

Prior to hydrotime modeling, the germination capacity (\%) and time $(\mathrm{t})$ of germination through the different water potential treatments were evaluated. Germination capacity was statistically compared using GLMs with a binomial distribution in Ime4 package (Bates et al., 2015) in R software (R Core Team, 2018), considering distilled water $(\Psi=0)$ as the control (baseline) in the analysis. Observed t was calculated to different germination percentiles $(10,30,50$ and $70 \%)$ by linear interpolation of two nearest points in the germination curves, then obtaining the $x$-axis interception to the corresponding fraction (Steinmaus et al., 2000). Model parameters were obtained for two hydrotime models: graphic model and probit model. In the graphic model, the germination rates for the different germination fractions $\left(\mathrm{GR}_{(\mathrm{g})}=1 / \mathrm{t}\right)$ were regressed against the treatments to assess the linearity among $G R$ and water potential (Bradford, 1990). Base water potential $(\Psi \mathrm{b})$ was estimated as the point which the regression lines intercepted the $x$-axis $(G R=0)$, while hydrotime $\left(\theta_{H}\right)$ was obtained as the inverse of regression line slope $\left(\theta_{H}=1 /\right.$ slope), according to Gummerson (1986).

In the probit model, germination percentages were transformed to probit units and plotted as function of $\Psi \mathrm{b}$. Linear regression was used to evaluate the relationship between observed germination and the predicted line. The value of $\theta_{H}$ was probed repeated times and considered the best-fitting values which showed higher $R^{2}$ and least residual model (Dahal and Bradford, 1994; Bradford, 1995). Predicted germination curve was derived from the original probit regression line (Table 1) using a normal distribution in Excel ${ }^{\circledast}$ (Cardoso, 2011). Once obtained hydrotime parameters of both models, germination times were estimated by rearranging the basic equation: $\theta_{H}=(\Psi-\Psi \mathrm{b}) \cdot \mathrm{t}_{(\mathrm{g})^{\prime}}$ thus considering $t_{(g)}=\theta_{H} /(\Psi-\Psi b)$. Hence, the model-predicted germination times were calculated for the 10 and $50 \%$ percentiles (t10 and t50) and compared to observed t-values in relation to confidence intervals (95\%). Because $\Psi \mathrm{b}$ is plotted in the $x$-axis in the probit model, the following equation was considered: $t_{(g)}=\theta_{H} /(\Psi-(($ probitG-a) $/ b)$, where "a" is the intercept, and "b" the slope of the probit regression. 
Table 1. Parameters of hydrotime model regression lines: equation and $R^{2}$, base water potential $(\Psi \mathrm{b}, \mathrm{MPa})$ and hydrotime values $\left(\theta_{\mathrm{H}}\right)$ for seed germination of Peltophorum dubium.

\begin{tabular}{ccccc}
\hline & Equation & $\mathrm{R}^{2}$ & $\Psi$-base & $\theta_{\mathrm{H}}$ \\
\hline Graphic model 10\% & $\mathrm{y}=0.559 \mathrm{x}+0.526$ & 0.98 & -0.94 & 1.8 \\
Graphic model 30\% & $\mathrm{y}=0.488 \mathrm{x}+0.435$ & 0.97 & -0.89 & 2.0 \\
Graphic model 50\% & $\mathrm{y}=0.480 \mathrm{x}+0.390$ & 0.95 & -0.81 & 2.1 \\
Graphic model 70\% & $\mathrm{y}=0.448 \mathrm{x}+0.328$ & 0.99 & -0.73 & 2.2 \\
Probit model & $\mathrm{y}=5.480 \mathrm{x}+3.866$ & 0.88 & $-0.7 \pm 0.18$ & 1.8 \\
\hline
\end{tabular}

The graphic model was performed for different germination fractions $(10,30,50$ and $70 \%)$, while $\psi \mathrm{b}$ of probit model regards to $50 \%$ of seed germination \pm standard deviation.

\section{RESULTS AND DISCUSSION}

Seeds showed high germination capacity (90\%) in water potentials of 0 and $-0.3 \mathrm{MPa}$, with a significant reduction to $\sim 70 \%$ at $-0.5 \mathrm{MPa}$, decreasing to $\leq 10 \%$ at -0.7 and $-0.9 \mathrm{MPa}$ (Figure 1). Germination was null under the treatments of $-1.1,-1.3$ and -1.5 MPa. Germination rates showed a linear relationship with water potential, decreasing GR according to the reduction of $\Psi$ and showing a general parallel pattern among the different germination fractions $(10,30,50$ and $70 \%$; Figure 2). Therefore, the interception points in the $x$-axis showed $\Psi \mathrm{b}$-values varying from -0.7 to $-0.9 \mathrm{MPa}$ among percentiles in the graphic model (Table 1). Regression lines for the different germination fractions in the graphic model showed slope ranging from 0.448 to 0.559 and $\theta_{H}$ values (1/slope) around $2.0 \mathrm{MPa}$ day (Table 1). Because the parallel lines show a relatively similar slope (i.e., a similar hydrotime for different germination percentiles), it is the $\Psi \mathrm{b}$ which drives germination parameters of the germination fractions.

In the probit model, it was possible to clump the different germination curves (Figure $3 \mathrm{~A}$ ) into a single curve of germination percentages as function of $\Psi \mathrm{b}$ (Figure $3 \mathrm{~B}$ ). Base water potential followed a normal distribution in the probit model, which described $88 \%$ of germination parameters, showing $\theta_{H}=1.8 \mathrm{MPa}$ day (Table 1 ). On the other hand, probit model might underestimate seed tolerance to low water potentials $\left(\Psi \mathrm{b}_{(50)}=-0.7 \mathrm{MPa}\right)$, whereas graphic model predicts a little more negative $\Psi \mathrm{b}$ value for the $50 \%$ fraction (-0.8 MPa; Table 1$)$. Nevertheless, predicted times

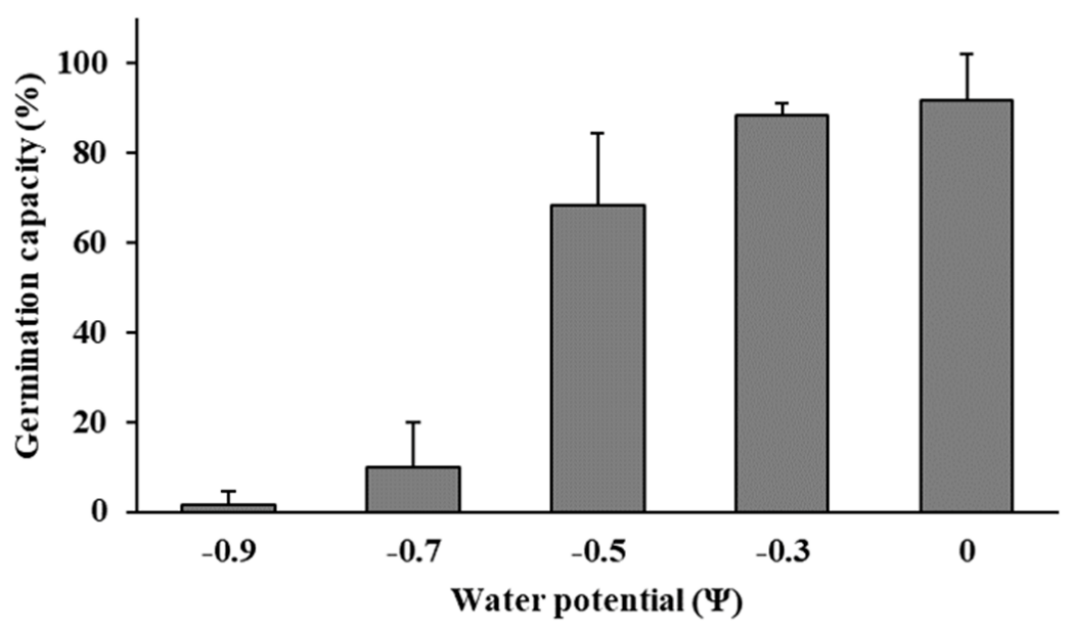

$\mathrm{P}$ value $=0.003$ under $\Psi$ of $-0.5 \mathrm{MPa}$ in relation to control (distilled water $0 \mathrm{MPa}$ ), and $\mathrm{P}<0.001$ under $\Psi \leq-0.7 \mathrm{MPa}$ compared to control.

Figure 1. Germination capacity (\%, mean \pm SD) of Peltophorum dubium seed germination under different water potentials $(\Psi, \mathrm{MPa})$, showing significant decrease under reduced water potentials. 


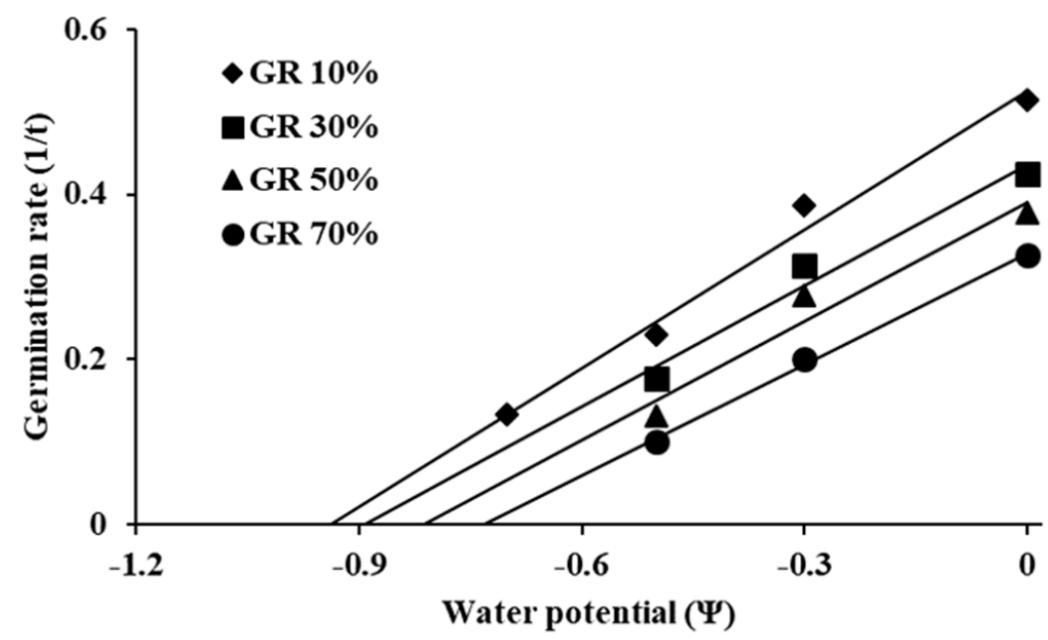

Continuous lines are linear regressions predicted by graphic model.

Figure 2. Relationships of germination rate $(G R)$ under different water potentials for different germination fractions $(10,30,50$ and $70 \%)$.
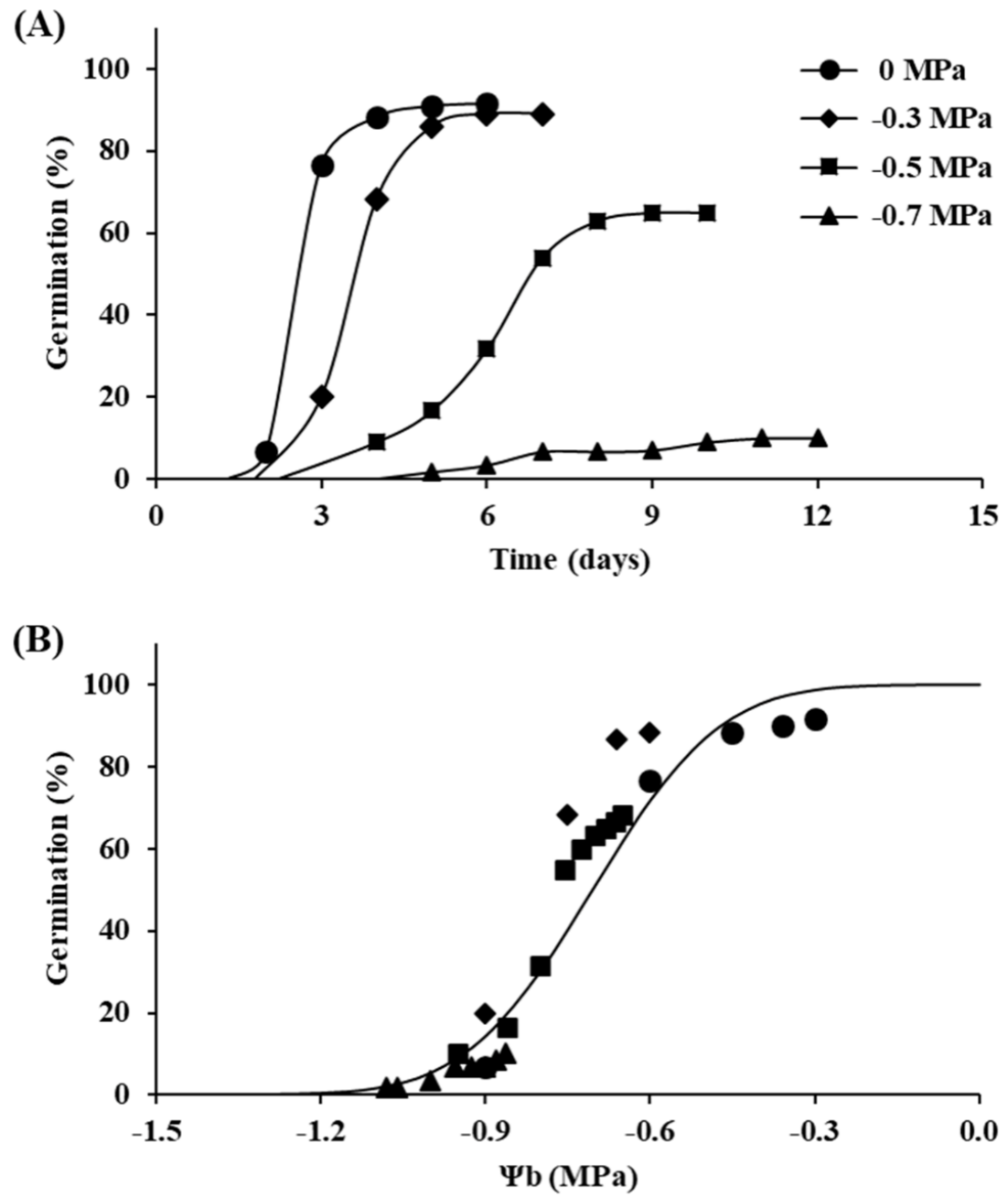

Figure 3. (A) Seed germination curves (cumulative germination percentage vs. time, in days) under different water potentials of $0,-0.3,-0.5$ and $-0.7 \mathrm{MPa}$. (B) Germination curve as function of $\Psi \mathrm{b}$ showing a normal distribution pattern (continuous line) predicted by probit model. 
of germination (t10 and t50) under different water potentials mostly fell within the confidence intervals of observed times, both for graphic and probit models (Table 2). Whether falling outside the confidence intervals, the error in germination time predictions never exceed one day more than the observed times. Germination times to $10 \%$ of seed germination (t10) were around two days under distilled water (0 MPa) and slowed to eight days under $-0.7 \mathrm{MPa}$. Similarly, t50 ranged from 2.5 to 8.8 days under 0 to $-0.5 \mathrm{MPa}$, and such fraction was never reached under water potentials $\leq-0.7 \mathrm{MPa}$ (Table 2 ).

Seeds of $P$. dubium fitted hydrotime presupposes, following patterns predicted by graphic and probit models. Models described seed germination parameters and predicted germination times similarly to found in crops throughout the world (Gummerson, 1986; Dahal and Bradford, 1994; Windauer et al., 2007; Patanè et al., 2009). Fitting hydrotime models in native trees may thus aid in seed testing analysis by describing the potential of a given species or population to tolerate moisture stress (Bradford and Still, 2004). Moreover, $\theta_{H}$ values provide information on time to emergence, predicting germination under continuous variables.

Among forest trees, changing in germination times and $\Psi \mathrm{b}$ seems to explain germination responses of pioneer species in tropical ecosystems (Daws et al., 2008). In our study species, seed tolerance to lower $\Psi$ was relatively sensitive compared to weed species, for instance, which may tolerate values <-1.0 MPa (Boddy et al., 2012). Some species from desert communities may also germinate under lower $\Psi$-values, such as Erodium texanum, which shows $\Psi \mathrm{b}$ of $-2.32 \mathrm{MPa}$ (Huang et al., 2016), while our study species never germinated under values lower than -0.9 MPa. Therefore, moisture stress seems to be a constraining factor for seed germination of $P$. dubium seeds, which might be recruited during less stressful conditions during the rainy season.

Likewise, seeds of Senna spectabilis were relatively sensitive to $\Psi$, but tolerance to moisture stress seems to be increased when seeds are subjected to dehydration cycles, thus helping their survival under drought conditions (Lima et al., 2018). Moreover, we argue threshold models can be used to compare germination requirements among species and/or populations in contrasting environments (Rosbakh and Poschlod, 2015; Tudela-Isanta et al., 2018; Picciau et al., 2019) thus providing insights on community assembly rules (Poschlod et al., 2013). Seeds of seasonal environments may face drought stress which may hamper germination and establishment (Cavallaro et al., 2016), and seed modeling may help to choose species for reforestation programs. Therefore, the hydrotime approach is an underexplored tool in the ecological management of tropical plant communities (Bradford, 2005).

Table 2. Observed (mean $\pm 95 \%$ confidence interval) and predicted germination times (graphic model and probit model) for 10 and $50 \%$ of seed germination (t10 and t50) of Peltophorum dubium seeds in different water potentials.

\begin{tabular}{ccccc}
\hline$\Psi(\mathrm{MPa})$ & Observed & Graphic model & Probit model \\
\hline 0 & & $\mathrm{t} 10$ & & \\
\hline-0.3 & $1.97 \pm 0.31$ & & 2.17 & 2.92 \\
-0.5 & $2.61 \pm 0.39$ & 4.18 & 4.10 \\
-0.7 & $4.55 \pm 1.43$ & & 8.63 & 7.53 \\
-0.9 & $8.0 \pm 3.20$ & - & - & - \\
\hline & - & & & 2.55 \\
-0.3 & & & 2.51 & 4.44 \\
-0.5 & $2.67 \pm 0.33$ & 3.97 & 8.76 \\
-0.7 & $3.61 \pm 0.17$ & & 6.51 & - \\
-0.9 & $8.28 \pm 3.65$ & & - & - \\
\hline
\end{tabular}

The germination was null under water potentials $\leq-0.9 \mathrm{MPa}$. 
The results provide a preliminary approach on hydrotime models, by testing the basic assumptions of the models and linear relationships with water potential (Bradford, 1995). Likewise, most model presupposes were followed by $P$. dubium seeds under different temperatures, described by thermal time models (Daibes and Cardoso, 2018). Temperature and water potential show important interactions to describe germination parameters under laboratory conditions (Alvarado and Bradford, 2002). However, few studies were accounted for such interactions (hydrothermal time) in Brazilian species (Simão et al., 2010; Oliveira et al., 2019). Seedling emergence from soil seedbanks should also be examined, in order to validate such models under field conditions (Forcella et al., 2000).

Some critics were made to probit analysis due the lack of independency among germination counting through the days. Therefore, cumulative germination percentages would be temporally dependent, breaking the principle of independency among samples in a regression analysis (Hay et al., 2014). Solving this issue would require a considerable higher amount of seeds, often impossible to achieve from native populations. Analysis derived from semi-parametric distributions (survival analysis, for instance) could help us to fix such problems by taking in account the probability of individual seeds to germinate or fail (Onofri et al., 2010; McNair et al., 2012). Despite such relatively recent approaches proposed, their connection to hydrotime assumptions and usage in statistical software remains a matter of inquiry (Cao et al., 2013).

Nevertheless, the predictions of germination times from linear models showed to be useful, showing biological relevance (Bradford, 1995; Bradford and Still, 2004). Therefore, germination parameters may be drawn from relatively simpler equations, and the advantage of probit model is to derive predictions of germination time from a single line. The graphic model, on the other hand, requires different regression lines according to the desired germination fraction wished to describe (Daibes and Cardoso, 2018). Either way, the application of a model does not exclude the use of other methods to predict seed germination. Linear relationship of GR and water potential may be helpful to achieve general patterns of model presupposes and can serve as a support to evaluate germination behavior before running probit analysis.

\section{CONCLUSIONS}

Hydrotime models describe germination of a forest tree and the applicability of such models for seed testing and/or ecological purposes is still underestimated. Future studies should account for the variation in seed germination within and among species and the interactions of water potential with temperature. Field experiments would be warranted for validation of model descriptions under natural variation.

\section{ACKNOWLEDGEMENTS}

This study was partially financed by the Coordenação de Aperfeiçoamento de Pessoal de Nível Superior (CAPES) Finance Code 001, and the authors received grants from Conselho Nacional de Desenvolvimento Científico e Tecnológico (CNPq).

\section{REFERENCES}

ALVARADO, V.; BRADFORD, K.J. A hydrothermal time model explains the cardinal temperatures for seed germination. Plant Cell and Environment, v.25, p.1061-1069, 2002. doi: https://onlinelibrary.wiley.com/doi/full/10.1046/j.1365-3040.2002.00894.x

BARNEBY, R.C. Neotropical Fabales at NY: asides and oversights. Brittonia, v.48, n.2, p.174-187, 1996. https://link.springer.com/ article/10.2307/2807811

BATES, D.; MAECHLER, M.; BOLKER, B.; WALKER, S. Fitting linear mixed-effects models using Ime4. Journal of Statistical Software, v.67, p.1-48, 2015. doi: https://www.jstatsoft.org/article/view/v067i01/0 
BEWLEY, J.D.; BRADFORD, K.J.; HILHORST, H.W.M.; NONOGAKI, H. Seeds: physiology of development, germination and dormancy. $3^{\text {rd }}$ ed. New York: Springer, 2013.

BODDY, L.G.; BRADFORD, K.J.; FISCHER, A.J. Population-based threshold models describe weed germination and emergence patterns across varying temperature, moisture and oxygen conditions. Journal of Applied Ecology, v.49, p.1225-1236, 2012. https:// besjournals.onlinelibrary.wiley.com/doi/epdf/10.1111/j.1365-2664.2012.02206.x

BOTELHO, B.A.; PEREZ, S.C.J.G.A. Estresse hídrico e reguladores de crescimento na germinação de sementes de canafístula. Scientia Agricola, v.58, n.1, p.43-49, 2001. http://www.scielo.br/scielo.php?script=sci_arttext\&pid=S0103-90162001000100008

BRADFORD, K.J. A water relations analysis of seed germination rates. Plant Physiology, v.94, p.840-849, 1990. http://www. plantphysiol.org/content/plantphysiol/94/2/840.full.pdf

BRADFORD, K.J. Water relations in seed germination. In: KIGEL, J.; GALILI, G. (ed.). Seed development and germination. New York: Marcel Dekker, 1995. p.351-396.

BRADFORD, K.J. Applications of hydrothermal time to quantifying and modeling seed germination and dormancy. Weed Science, v.50, n.2, p.248-260, 2002. https://www.cambridge.org/core/journals/weed-science/article/applications-of-hydrothermal-timeto-quantifying-and-modeling-seed-germination-and-dormancy/4C25559CD8877541424A6FFCC8E8F730

BRADFORD, K.J. Threshold models applied to seed germination ecology. New Phytologist, v.165, n.2, p.338-341, 2005. https://nph. onlinelibrary.wiley.com/doi/full/10.1111/j.1469-8137.2004.01302.x

BRADFORD, K.J.; STILL, D.W. Applications of hydrotime analysis in seed testing. Seed Technology, v.26, n.1, p.75-85, 2004. https:// www.jstor.org/stable/23433495?seq=1\#metadata_info_tab_contents

CAO, R.; FRANCISCO-FERNÁNDEZ, M.; ANAND, A.; BASTIDA, F.; GONZÁLEZ-ANDÚJAR, J.L. Modeling Bromus diandrus seedling emergence using nonparametric estimation. Journal of Agricultural, Biological and Environmental Statistics, v.18, n.1, p.64-86, 2013. https://link.springer.com/article/10.1007/s13253-012-0122-x

CARDOSO, V.J.M. Metodologia para análise da dependência térmica da germinação pelo modelo de graus-dia. Oecologia Australis, v.15, n.2, p.236-248, 2011. https://revistas.ufrj.br/index.php/oa/article/view/8126

CARDOSO, V.J.M.; PEREIRA, F.J.M. Dependência térmica da germinação de sementes de Drymaria cordata (L.) Willd. ex Roem. and Schult. (Cariophyllaceae). Acta Botanica Brasilica, v.23, n.2, p.305-312, 2009. http://www.scielo.br/scielo.php?script=sci_ arttext\&pid=S0102-33062009000200002

CARDOSO, V.J.M.; PEREIRA, F.J.M. Germinação de sementes de Drymaria cordata (L.) Willd. Ex Roem and Schult.: efeito do potencial hídrico. Brazilian Journal of Botany, v.31, n.2, p.253-261, 2008. http://www.scielo.br/scielo.php?script=sci_ arttext\&pid=S0100-84042008000200008

CARVALHO, P.E.R. Canafístula. In: EMBRAPA, Circular técnica no 64, 2002. Available on <https://www.infoteca.cnptia.embrapa.br/ bitstream/doc/306466/1/CT0064.pdf>. Accessed on November $14^{\text {th }}$.

CAVALLARO, V.; BARBERA, A.C.; MAUCIERI, C.; GIMMA, G.; SCALISI, C.; PATANÈ, C. Evaluation of variability to drought and saline stress through the germination of different ecotypes of carob (Ceratonia siliqua L.) using a hydrotime model. Ecological Engineering, v.95, p.557-566, 2016. https://www.sciencedirect.com/science/article/pii/S0925857416303664

DAHAL, P.; BRADFORD, K.J. Hydrothermal time analysis of tomato seed germination at suboptimal temperature and reduced water potential. Seed Science Research, v.4, n.2, p.71-80, 1994. https://www.cambridge.org/core/journals/seed-science-research/ article/hydrothermal-time-analysis-of-tomato-seed-germination-at-suboptimal-temperature-and-reduced-water-potential/10AD DA1DEF20CA7F4D267C6BB969440F

DAIBES, L.F.; CARDOSO, V.J.M. Seed germination of a South American forest tree described by linear thermal time models. Journal of Thermal Biology, v.76, p.156-164, 2018. https://www.ncbi.nlm.nih.gov/pubmed/30143290

DAWS, M.I.; CRABTREE, L.M.; DALLING, J.W.; MULLINS, C.E.; BURSLEM, D.F.R.P. Germination responses to water potential in neotropical pioneers suggest large-seeded species take more risks. Annals of Botany, v.102, n.6, p.945-951, 2008. https://academic. oup.com/aob/article/102/6/945/105407 
DUARTE, A.A.; LEMOS-FILHO, J.P.; MARQUES, A.R. Seed germination of bromeliad species from the campo rupestre: thermal time requirements and response under predicted climate-change scenarios. Flora, v.238, p.119-128, 2018. https://www.sciencedirect. com/science/article/pii/S0367253017332280

FINCH-SAVAGE, W.E. The use of population-based threshold models to describe and predict the effects of seedbed environment on germination and seedling emergence of crops. In: BENECH-ARNOLD, R.L.; SÁNCHEZ, R.A. (ed.). Handbook of seed physiology: applications to agriculture. New York: Haworth Press, 2004. p.51-96.

FONSECA, S.C.L.; PEREZ, S.C.J.G.A. Ação do polietileno glicol na germinação de sementes de Adenanthera pavonina L. e o uso de poliaminas na atenuação do estresse hídrico sob diferentes temperaturas. Revista Brasileira de Sementes, v.25, n.1, p.1-6, 2003. http://www.scielo.br/scielo.php?script=sci_arttext\&pid=S0101-31222003000100001

FORCELLA, F.; BENECH ARNOLD, R.L.; SANCHEZ, R.; GHERSA, C.M. Modeling seedling emergence. Field Crops Research, v.67, n.2, p.123-139, 2000. https://pubag.nal.usda.gov/download/25689/PDF

GARCIA-HUIDOBRO, J.; MONTEITH, J.L.; SQUIRE, G.R. Time, temperature and germination of Pearl Millet (Pennisetum typhoides S. and H.). Journal of Experimental Botany, v.33, n.2, p.297-302, 1982. https://academic.oup.com/jxb/article-abstract/33/2/297/634 294?redirectedFrom=fulltext

GUMMERSON, R.J. The effect of constant temperatures and osmotic potentials on the germination of sugar beet. Journal of Experimental Botany, v.37, n.6, p.729-741, 1986. https://academic.oup.com/jxb/article-abstract/37/6/729/452586?redirectedFr om=fulltext

HAY, F.R.; MEAD, A.; BLOOMBERG, M. Modelling seed germination in response to continuous variables: use and limitations of probit analysis and alternative approaches. Seed Science Research, v.24, n.3, p.165-186, 2014. https://www.cambridge.org/core/ journals/seed-science-research/article/modelling-seed-germination-in-response-to-continuous-variables-use-and-limitations-ofprobit-analysis-and-alternative-approaches/2AAB3BD01B32CEBE5DB9E3FAC8341A73

HUANG, Z.; LIU, S.; BRADFORD, K.J.; HUXMAN, T.E.; VENABLE, L. The contribution of germination functional traits to population dynamics of a desert plant community. Ecology, v.97, n.1, p.250-261, 2016. https://esajournals.onlinelibrary.wiley.com/doi/epdf/10.1890/150744.1

LIMA, A.T.; CUNHA, P.H.J.; DANTAS, B.F.; MEIADO, M.V. Does discontinuous hydration of Senna spectabilis (DC.) H.S. Irwin and Barneby var. excelsa (Schrad.) H.S. Irwin and Barneby (Fabaceae) seeds confer tolerance to water stress during seed germination? Journal of Seed Science, v.40, n.1, p.36-43, 2018. http://www.scielo.br/scielo.php?script=sci_arttext\&pid=S2317-15372018000100036\&lng=en \&nrm=iso\&tlng=en

MCNAIR, J.N.; SUNKARA, A.; FROBISH, D. How to analyze seed germination data using statistical time-to-event analysis: nonparametric and semi-parametric methods. Seed Science Research, v.22, n.2, p.77-95, 2012. https://www.cambridge.org/ core/journals/seed-science-research/article/how-to-analyse-seed-germination-data-using-statistical-timetoevent-analysisnonparametric-and-semiparametric-methods/257AFB74E845B5792FD8FEE27ADE03B4

MICHEL, B.E.; KAUFMANN, M.R. The osmotic potential of polyethylene glycol 6000. Plant Physiology, v.51, p.914-916, 1973. http:// www.plantphysiol.org/content/plantphysiol/51/5/914.full.pdf

OLIVEIRA, G.M.; SILVA, F.F.S.; ARAUJO, M.N.; COSTA, D.C.C.; GOMES, S.E.V.; MATIAS, J.R.; ANGELOTTI, F.; CRUZ, C.R.P.; SEAL, C.E.; DANTAS, B.F. Environmental stress, future climate and germination of Myracrodruon urundeuva seeds. Journal of Seed Science, v.41, n.1, p.32-43, 2019. doi: 10.1590/2317-1545v41n1191945

ONOFRI, A.; GRESTA, F.; TEI, F. A new method for the analysis of germination and emergence data of weed species. Weed Research, v.50, p.187-198, 2010. https://onlinelibrary.wiley.com/doi/epdf/10.1111/j.1365-3180.2010.00776.x

PATANÈ, C.; CAVALLARO, V.; COSENTINO, S.L. Germination and radicle growth in unprimed and primed seeds of sweet sorghum as affected by reduced water potential in $\mathrm{NaCl}$ at different temperatures. Industrial Crops and Products, v.30, n.1, p.1-8, 2009. https:// www.sciencedirect.com/science/article/pii/S0926669008002379

PICCIAU, R.; PRITCHARD, H.W.; MATTANA, E.; BACCHETTA, G. Thermal thresholds for seed germination in Mediterranean species are higher in mountain compared with lowland areas. Seed Science Research, v.29, n.1, p.44-54, 2019. https://www.cambridge. org/core/journals/seed-science-research/article/thermal-thresholds-for-seed-germination-in-mediterranean-species-are-higherin-mountain-compared-with-lowland-areas/6836A5DB191BAD484F947564BF0EBDD4 
PIRES, L.A.; CARDOSO, V.J.M.; JOLY, C.A.; RODRIGUES, R.R. Germination of Ocotea pulchella (Nees) Mez (Lauraceae) seeds in laboratory and natural restinga environment conditions. Brazilian Journal of Biology, v.69, n.3, p.935-942, 2009. http://www.scielo. br/scielo.php?script=sci_abstract\&pid=S1519-69842009000400023\&lng=pt\&nrm=iso\&tlng=en

PEREZ, S.C.J.G.A.; FANTI, S.C.; CASALI, C.A. Influência da luz na germinação de sementes de canafístula submetidas ao estresse hídrico. Bragantia, v.60, n.3, p.155-166, 2001. http://www.scielo.br/scielo.php?script=sci_arttext\&pid=S0006-87052001000300002

POSCHLOD, P.; ABEDI, M.; BARTELHEIMER, M.; DROBNIK, J.; ROSBAKH, S.; SAATKAMP, A. Seed ecology and assembly rules in plant communities. In: VAN DER MAAREL, E.; FRANKLIN, J. (ed.). Vegetation Ecology, $2^{\text {nd }}$ ed. John Wiley \& Sons, 2013. p.164-202.

R CORE TEAM. $R$ : a language and environment for statistical computing. Vienna, Austria: R Foundation for Statistical Computing, 2018. Available on: https://www.R-project.org/. Accessed on November $18^{\text {th }}$.

REGO, S.S.; FERREIRA, M.M.; NOGUEIRA, A.C.; GROSSI, F. Influência de potenciais osmóticos na germinação de sementes de Anadenanthera colubrina (Veloso) Brenan (Angico-branco) - Mimosaceae. Revista Brasileira de Biociências, v.5, n.S2, p.549-551, 2007. http://www.ufrgs.br/seerbio/ojs/index.php/rbb/article/view/484/421

ROSBAKH, S.; POSCHLOD, P. Initial temperature of seed germination as related to species occurrence along a temperature gradient. Functional Ecology, v.29, p.5-14, 2015. https://besjournals.onlinelibrary.wiley.com/doi/epdf/10.1111/1365-2435.12304

SIMÃO, E.; TAKAKI, M.; CARDOSO, V.J.M. Germination response of Hylocereus setaceus (Salm-Dyck ex DC.) Ralf Bauer (Cactaceae) seeds to temperature and reduced water potentials. Brazilian Journal of Biology, v.70, n.1, p.135-144, 2010. http://www.scielo.br/ scielo.php?script=sci_arttext\&pid=S1519-69842010000100019

STEINMAUS, S.J.; PRATHER, T.S.; HOLT, J. Estimation of base temperatures for nine weed species. Journal of Experimental Botany, v.51, n.343, p.275-286, 2000. https://www.researchgate.net/publication/12381578_Estimation_of_base_temperature_for_nine_ weed_species

TUDELA-ISANTA, M.; LADOUCEUR, E.; WIJAYASINGHE, M.; PRITCHARD, H.W.; MONDONI, A. The seed germination niche limits the distribution of some plant species in calcareous or siliceous alpine bedrocks. Alpine Botany, v.128, p.83-95, 2018. https://www. readcube.com/articles/10.1007\%2Fs00035-018-0199-0

VILLELA, F.A.; DONI-FILHO, L.; SEQUEIRA, E.L. Tabela de potencial osmótico em função da concentração de polietilenoglicol 6.000 e da temperatura. Pesquisa Agropecuária Brasileira, v.26, p.1957-1968, 1991.

WINDAUER, L.; ALTUNA, A.; BENECH-ARNOLD, R. Hydrotime analysis of Lesquerella fendleri seed germination responses to priming treatments. Industrial Crops and Products, v.25, n.1, p.70-74, 2007. https://www.sciencedirect.com/science/article/pii/ S0926669006000987 use, distribution, and reproduction in any medium, provided the original work is properly cited. 